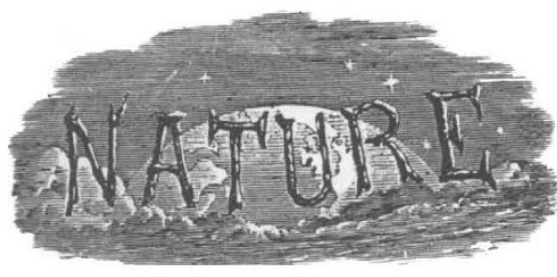

SATURDAY, AUGUST 8, I93I.

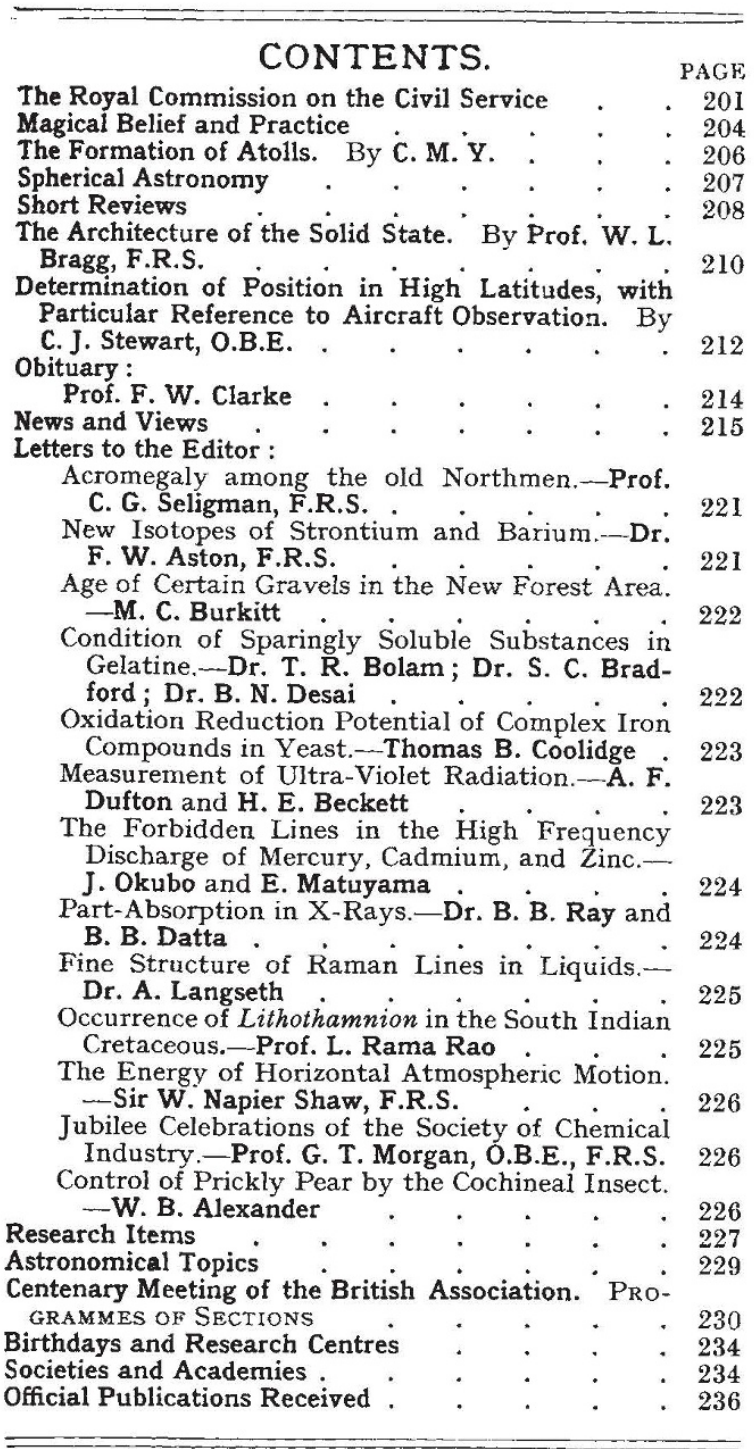

Editorial and Publishing Offices:

MACMILLAN \& CO., LTD.,

ST. MARTIN'S STREET, LONDON, W.C. 2 .

Editorial communications should be addressed to the Editor.

Advertisements and business letters to the Publishers.

Telephone Number: GERRARD 8830.

Telegraphic Address: PHUSIS, WESTRAND, LONDON.

\section{The Royal Commission on the Civil Service.*}

$\mathrm{R}$ EADERS of NATURE will recall that when the present Government announced its intention of setting up a Royal Commission on the Civil Service, with terms of reference of a seemingly comprehensive character, our satisfaction was qualified by a contemplation of the list of the members of the Commission. Without in any way belittling the attainments and achievements of its sixteen members in their respective avocations, we were compelled to point out that not one was a scientific man or engaged in the application of science to the needs of the community, and that not one was known to have devoted consideration to the more fundamental problems of public administration.

The Commission has now issued a conscientious and painstaking Report, the character of which has confirmed all too well the misgivings which we expressed at the time of its appointment. The Commission shows itself to be dominated almost entirely by the official witnesses, who view with complacency an administrative structure designed by them in relation to the needs of an earlier and more primitive social organisation. It is entitled to credit for having studied and answered-though usually in the negative-the numerous and often constructive criticisms brought to its notice by staff organisations; but it must be rarely that a Royal Commission, confronted with a problem of the magnitude indicated by the terms of reference, can have been so sterile of constructive ideas of its own, and so content to put forward mere glosses on an existing structure, many features of which, so far as it has been modernised, were hurriedly improvised in the immediate post-War years.

Those of us who attribute in no small measure the difficulties with which Great Britain is confronted to failure to give full scope to the scientific and technical expert, had our hopes raised by the inclusion in the terms of reference of the Commission of an instruction to inquire into and report upon the "structure and organisation of the Civil Service". We have never pretended that scientific and technical men and women are not concerned with ques. tions of remuneration, but it has always been our view that remuneration would adjust itself once the true function of the expert had been recognised and his status duly adjusted. The Commissioners, however, following the unfortunate precedent of the Carpenter Committee on the staffs of Government

* Royal Commission on the Civil Service, 1929-31. Report. (Cmd. 3909.) Pp. viji + 252. (London: H.M. Stationery Office, 1931.) $3 s .6 d$. net.

No. 3223, VoL. 128] 
scientific establishments, have carefully avoided consideration of any fundamental questions of structure, including especially those arising out of the employment of specialists-to use a wide term to comprehend professional, scientific, and technical staffs-in the administrative departments of State. The Commissioners' interpretation of the above essential element in their terms of reference is as follows :

"It is not our duty to redistribute the functions of Government between Departments, or to reorganise or determine the staff of a Department. But, taking things as they are, it is our duty to determine the most satisfactory general principles to be followed, in regulating recruitment, in fixing terms and conditions of employment, in classifying grades or classes, in distributing functions between grades and classes, and in other like matters."

Two large-scale official inquiries, one dealing with the State scientific services and one dealing with the Civil Service as a whole, have thus seen fit to avoid investigating the wider questions of structure and organisation, beside which matters of staffing, remuneration, and conditions of employment fade into insignificance. There was much in the Report of the Carpenter Committee which could be welcomed as revealing some perception of the need for the development of a State scientific service, even although the problem was not actually visualised in this form, but was approached as a mere simplification of grading and scales of pay so as to ensure uniformity among staffs employed on comparable duties in different departments. Nevertheless, whatever the approach, the Carpenter Report represented progress. The present Royal Commission's Report, however, is little more than a laudation of the status quo and an endorsement of Treasury principles and practice based upon conceptions of the scope of public administration current in the latter part of the last century. Without touching on larger questions of administrative policy, however, there were certain proposals with which the Commission deemed itself competent to deal and which were elaborated in the evidence of the Institution of Professional Civil Servants and supported from other points of view by both the British Science Guild and the Association of Scientific Workers.

In the first place, specialist officers are denied a proper share in the formation of policy, a function which resides in the hands of non-technical administrators who alone are entitled to access to the supreme authority represented by the Minister ; in the second place, it is most exceptional for the professional or scientific officer, however gifted ad- ministratively, to enter the charmed circle of the administrators; and in the third place, there is a complete failure to perceive the fundamental unity which underlies the employment of technical experts by the State, a type of recognition which in other walks of life-even on the administrative side of the Civil Service-has done much to promote esprit de corps, the pre-requisite of administrative efficiency.

There can be no doubt that, in the interests of efficiency, the technical hierarchies should be accorded a status equal to that of the administrative hierarchies, and that, in particular, the chief technical officer in a department should rank on terms of practical equality with the administrative head of the department. When policy is in course of formation or when larger decisions are being taken, the chief technical adviser should be permitted to play as prominent a part as the chief administrative adviser of the Minister, and the board system in one form or another seems peculiarly suitable for securing this result. Under the present system it frequently happens that the technical staff prepare a report and guide the hands of the administrators up to a certain point and then hear no more about the Minister's views until perhaps there is a public pronouncement on the platform or in parliament.

The Commissioners state that they heard no evidence to justify the view that at the present time specialists are disregarded. This statement is apparently based upon the fact that a long series of permanent secretaries expressed complacent satisfaction with the present system. If the Commissioners had heard first-hand information on the point, from professional and scientific heads of departments, we have little doubt that they would then have been satisfied that there is a case for a reform of the present system. They have been misinformed when they assert that " there is no real danger that their (specialist) advice would not be placed before the Minister or official on whom falls the responsibility for the final decision on the issue under consideration ".

Nevertheless, the Commissioners are constrained to admit that there may still exist among specialists a feeling that their advice is not always sought and considered, and the pious remedy proposed is that

"those in positions of administrative responsibility should take special precautions to ensure not merely that specialists are properly consulted and that full consideration is given to their views, but that they are given no ground for feeling that their value is not appreciated. It is important 
that specialists as well as other officers whose duty it is to give advice should be made aware of the decision taken by the responsible authority."

It is precisely because these things do not happen as a matter of course under the present system that there is an urgent need for according the technical advisers a more assured status and a more definite right to assert their points of view in the presence of those who have to take the ultimate decision.

Accepting without qualification the official Treasury evidence, the Commissioners state that they have received no evidence indicating that, when an appointment to the permanent headship of a department is under consideration, regard is not and will not be had to the claims of officers other than those serving in an administrative eapacity, and in support of this statement they mention that two of the present permanent heads of departments began their careers on the specialist side of the Service. The Commissioners' findings on this important point are rather discounted. by a passage in the chapter of the Report devoted to the Post Office, in which, when discussing the position and remuneration of the engineer-in-chief, they state that they would

" have expected that over a period of years some technical officers would have been found to possess qualities rendering desirable their transfer to the administrative side. We were told, however, that no officer from the technical side had ever been promoted to an administrative post in the department."

We may remark in passing that entry into the administrative class may be obtained by those whose specialisation at the universities has not been in literary subjects, through the medium of the open competition for posts in the administrative class. This fact is apparently not generally known, and we propose to return to the subject in a subsequent issue. However, we would urge that the very fact that the ad. ministrative faculty in its highest sense is rare, renders it essential that the field from which administrators are drawn should be as wide as possible, and just as it is now repugnant that qualified persons should be denied public appointments on political, social, or religious grounds, so it should be equally accepted that no man should be virtually debarred from administrative preferment merely because he possesses precise and ordered knowledge of a particular branch of science.

Finally, there was the possibility of approach to the problem of raising the status of the technical expert by simplifying the extraordinarily heterogeneous collection of grades and salaries which obtains in the professional and technical services. As we have indicated, the Carpenter Committee made important recommendations, which are endorsed by the Commissioners, to secure greater uniformity in the scientific departments. According to the evidence submitted by the Institution of Professional Civil Servants, there are actually more than five hundred separate grades in the professional and technical services, revealing minute salary differences one from another, ostensibly based upon a fine weighing up by the 'estab. lishment' experts (all of whom are administrators) of the relative values of the services performed by these officers. One would have thought that a prima facie case for rationalisation would have been afforded by the history of the non-technical services, which in the past revealed the same multiplicity of grading, most of which has disappeared as a result of a process of 'reorganisa. tion'. A similar problem has confronted the Canadian technical service, and the recent report of the Canadian Royal Commission has recommended the replacement of 203 separate grades by seven simplified hierarchies.

This issue of simplification is something more than a desire for symmetry, for the acceptance of the principle that the grading and remuneration of professional and technical officers in different occupations should be unified would pave the way to that public recognition of the technical services of the State, which is a necessary pre. cursor to the granting to the staff concerned of a higher status in the official hierarchy. The Commissioners state that it was not possible for them to review in detail the organisation of the various specialist classes outside the terms of reference of the Carpenter Committee, nor, as we understand, did the Commissioners make any detailed investigation of the actual working of the professional and technical departments. The fact that they were without any real first-hand acquaintance with the specialist services did not prevent the Commissioners from pronouncing quite definitely against the various proposals to which we have referred for enhancing the status of the expert or from stating that there is no justification for an improvement in remuneration except in the case of some of the highest technical posts.

The constructive proposals put to the Commis. sion were rejected out of hand, with the qualification

No. 3223, Vou. 128] 
that the Commission admitted the extraordinary anomaly of paying between $£ 1600$ and $£ 1700$ a year to the engineer-in-chief at the Post Office, responsible for the technical side of the conduct of the State's telegraph and telephone enterprises, and for the control of an army of workmen and of professional and technical officers, whereas the secretary of the Post Office receives $£ 3000$ a year. The Commission recommends that the engineer-in-chief should receive $£ 2500$. This, coupled with a suggestion that the secretary of the Department of Scientific and Industrial Research, who now receives $£ 2200$, should receive $£ 2500$, and that in the highest professional posts adjustment of salaries is required, represents substantially the whole of the Commissioners' reactions to the suggestion that the employment of specialist officers by the State presents a special problem that requires reconsideration in the light of modern conditions.

When confronted by the problem of the Post Office, the Commissioners not unnaturally quailed, and took refuge in a suggestion that the importance of the issues raised by a State trading enterprise pointed to the need for a special committee or commission to inquire into Post Office organisation. It does not appear to have occurred to the Commissioners that a fortiori there was an overwhelming case for a special committee or commission to inquire into the even more difficult problem of the professional, scientific, and technical services, to which they admit they gave no detailed consideration.

While we have no hesitation in describing the Report as a disaster from the point of view of the welfare of the community, it would not be just to place the whole of the blame upon the Commissioners, many of whom, in view of their public position, must be regarded as being in close touch with informed public opinion. The failure to appreciate the significance of the expert in public administration is but a symptom of the more widespread failure to realise that the ills which now beset civilised communities can only be solved by scientific methor and the utilisation of scientific discovery. Our task must continue to be the creation of an informed public opinion which will instinctively exhibit indignation when important public questions involving scientific considerations are discussed without the assistance of experts, and will insist that on all public inquiries there should be a due representation of experts familiar with the subject matter of such inquiries.

No. 3223 , VoL. 128

\section{Magical Belief and Practice.}

(1) Amulets and Superstitions: the Original Texts with Translations and Descriptions of a Long Series of Egyptian, Sumerian, Assyrian, Hebrew, Christian, Gnostic, and Muslim Amulets and Talismans and Magical Figures, with Chapters on the Evil Eye, the Origin of the Amulet, the Pentagon, the Swăstika, the Cross (Pagan and Christian), the Properties of Stones, Rings, Divination, Numbers, the Kabbâlâh, Ancient Astrology, etc. By Sir E. A. Wallis Budge. Pp. xxxix $+543+22$ plates. (London : Oxford University Press, 1930.) 30s. net.

(2) Le livre de recettes d'un dabtara abyssin. Par Marcel Griaule. (Université de Paris : Travaux et mémoires de l'Institut d'Ethnologie, tome 12.) Pp. $x i+180$. (Paris: Institut d'Ethnologie, 1930.) 70 francs.

(1) DELIEF in the power of the amulet is one $B$ of the most interesting phenomena in the history of religious belief. In close alliance with 'magic' it appears as one of the earliest forms of man's belief in the forces which he believes to lie behind the perceptions of his senses: as the mascot it serves to testify to the last act of faith of a disintegrated religion. How closely the extremes of the scale approach one another appears in some instructions on the choice of amulets published a few years ago, in which the writer argued the possibility that there might be something in it on the analogy of wireless telegraphy. No anthropologist in search of mana in religious belief could desire a more illuminating example; but after saying this we hesitate to suggest that Sir Wallis Budge himself is not guiltless of flirting with the idea that " there may be something in it".

In his study of the amulet and allied beliefs, Sir Wallis Budge has confined himself to ancient Egypt and Babylonia, the later Kabbalists, the Gnostics, pagan and Christian, and the astrologers. Virtually his field is the ancient Mediterranean area. Within these limits he has covered the ground with no little thoroughness. In fact there is scarcely any aspect of magical belief and practice on which he has not touched. In addition, he has added to the evidence from his experience among makers of horoscopes, casters of nativities, diviners, crystalgazers, palmists, and fortune-tellers of all kinds whom he has met while engaged on official missions in Egypt, the Sudan, and Mesopotamia-a fruitful field as all will agree who know the superstitious reverence and profound belief with which such classes are regarded by the populace in these countries. 